\title{
The Limits and Power of Law: What the Absence of \#MeToo in Taiwan Can Tell Us about Legal Mobilization
}

Chao-ju Chen, National Taiwan University

doi:10.1017/S1743923X21000271

The \#MeToo movement gained global prominence after Hollywood celebrities came forward with their experiences of sexual violence and encouraged others to do the same. This was by no means the first time a woman had told the world of her experience of sexual violation, but this time, the powerful were paying attention: "Women have been saying these things forever. It is the response to them that has changed" (MacKinnon 2020, 7). High-quality investigative journalists vetted the women's accounts and provided more stories of sexual abuse and predation. Many survivors have since come forward with their own names and their perpetrators' names, leading some prominent men to be deprived of their fame and positions of power. The \#MeToo movement makes two things matter and count: what the victims say and what the perpetrators did. It has raised the perpetrators' accountability and the victims' credibility and reversed the scenario of sexual violation: making the perpetrator, not the victim, pay for the sexual harm.

Notwithstanding the controversies within feminism and the backlash against feminism, the \#MeToo movement is establishing roots and becoming more diverse. Its global reach takes many forms and directions. In Taiwan, a democratic country that considers itself a regional leader in gender equality, \#MeToo has become a symbol of anti-sexual violence activism, but it has yet to produce a crystallizing effect and recharge the anti-sexual violence movement. Despite the prevalence of social media platforms and a free press in Taiwan, hardly any survivors of sexual violence have publicly disclosed their identities or those of their perpetrators, calling for others to follow, and eventually leading to a collective demand for justice. No powerful men have been identified and held accountable as a result of their victims' public accusations. ${ }^{1}$ No significant structural and social changes have emerged to

1. It could be argued that the responses to the Lin Yi-han case count as a \#MeToo movement. After her death from suicide in 2017, Lin, a young and talented writer, was found to have turned her own experience into her acclaimed novel, which describes the story of a teenage model-student suffering from her teacher's sexual predation. In the wake of Lin's high-profile death, some survivors have been encouraged to come forward with their stories of sexual violation, but mainly in a veiled and anonymous way. It is difficult, if not impossible, to confirm the extent to which the novel matches Lin's life and whether it can considered an autobiography. The Lin Yi-han case is therefore not a 
significantly improve the victims' credibility and increase the perpetrators' and institutions' accountability. Sexual violence remains a phenomenon that is statutorily prohibited and publicly condemned, but stories are told in private, with victims in the dark and perpetrators enjoying impunity.

The \#MeToo movement serves as an indication of civil society's vibrant mobilization against sexual violence, but the absence of the \#MeToo movement in a society does not suggest that it lacks anti-sexual violence activism. Before global \#MeToo, activists in Taiwan pursued grassroots strategies and institutional venues to combat sexual violence. These efforts came to partial fruition in a series of legal changes, which included (1) the 1997 Sexual Assault Crime Prevention Act, which provides rape shield protection, that is, limits on the defense's ability to introduce evidence or to cross-examine a sexual assault victim about their prior sexual history with individuals other than the defendant, and prohibition of the disclosure of the identity of a victim; (2) a revised sexual assault law in the Penal Code of 1999 that redefines sexual assault as a violation of the right to sexual autonomy (not an offense against social morality), abolishes the resistance requirement, and adopts the "lack of consent" element; and (3) the 2002 Gender Equality in Employment Act, the 2004 Gender Equity Education Act, and the 2005 Sexual Harassment Prevention Act, which forbid sexual harassment in the workplace, on campuses, and in all aspects of social life.

These remarkable achievements in lawmaking raise questions about how the law relates to the absence of \#MeToo in Taiwan: does the absence of \#MeToo prove that the law has provided effective channels and sufficient remedies for victims so that they do not have to go to the court of public opinion for justice? Or does it suggest the undermobilization of the law in extralegal situations despite the failings of formal legal channels? Since the majority of sexual harassment victims in the workplace do not report or file complaints through formal channels (Chang 2018; Sheu 1999; Taiwan Ministry of Labor 2020; Taiwan Police Institute 2012), it is the latter thesis that is addressed in the following discussion.

\section{LEGAL MOBILIZATION IN THE COURT OF PUBLIC OPINION}

While \#MeToo has done what the law could not - that is, turning women into credible accusers - it sprung from the law on sexual harassment

catalyst of \#MeToo movement in Taiwan. This assessment, however, is not to be taken as a denial of its admirable contribution to the public awareness of sexual violence. 
(MacKinnon 2020). Emerging from the failings of formal reporting channels, \#MeToo has updated the map of unofficial reporting and informal accusations by revealing the "whisper networks" to outsiders and introducing new types of informal and open-access reporting channels: the "shadow" court of public opinion (anonymous allegations) and the "new" court of public opinion (named allegations) (Tuerkheimer 2019). The rebirth of \#MeToo in 2017 - a decade after Tarana Burke created the hashtag \#MeToo and one year after Kimberlé Crenshaw launched the \#SayHerName campaign - was initially triggered by prominent women making allegations against powerful men on social media platforms as well as in mainstream media, but the new court of public opinion has since been made available to survivors other than celebrities. The lack of public allegations made by prominent women in Taiwan is one of the reasons why \#MeToo is absent. The disengagement of investigative journalism, which plays a pivotal role in vetting stories and providing opportunities for rebuttal in the informal process of addressing sexual abuse (Clarke 2019), has further impeded the creation of the new court of public opinion.

Does it matter whether the "plaintiff" in the new court of public opinion is a prominent woman? On the one hand, the activism and work of women of color around the world is regularly overlooked or underrecognized (Fileborn and Loney-Howes 2019, 6; Noel and Oppenheimer 2020, xxi), but, on the other hand, privileged women's "wins" in the new court of public opinion can, and did, serve to empower survivors who do not have access to mainstream media and whose credibility can be easily challenged and ruined. \#MeToo began with a privileged few speaking out through extralegal channels, but it did not stop there.

The lack of famous plaintiffs in the court of public opinion in Taiwan speaks volumes about the state of sexual violence: the price and risk of speaking out are so high that both formal and informal channels fail to provide remedies for survivors of sexual violence. The privileged few might have more to lose by pressing charges against powerful men in the court of public opinion, but they also might have more protection and more access to mainstream media to confirm their stories of sexual abuse. The lack of investigative journalism might be a crucial factor contributing to survivors' decision to remain silent.

Going to the court of public opinion to claim sexual abuse is a form of participation in digital feminist activism, but it can also be seen as a form of informal legal mobilization. In her pivotal work, Zemans $(1983,690)$ casts legal mobilization as "a form of political activity by which the citizenry uses 
public authority on its own behalf." The \#MeToo movement has demonstrated that, in some cases, the court of public opinion has empowered survivors and imposed accountability on their perpetrators in ways that formal channels cannot provide. Claiming sexual abuse in the court of public opinion is to mobilize the law. Making a claim of sexual abuse in the court of public opinion is also a political act through which an individual citizen acts as a participant in the making and implementation of public policy. The trials and legal reforms that followed \#MeToo are a testament to how individual informal legal mobilization can lead to collective informal legal mobilization and collective formal legal mobilization.

In Taiwan, sexual harassment and sexual assault laws emerged from feminist legal mobilization long before \#MeToo, but undermobilization of the law in legal and extralegal forums has encumbered its improvement and enforcement. Scheingold $(1974,2004)$ has argued that "the myth of rights" may both empower and constrain those seeking change. The myth of rights might have contributed to feminist lawmaking in Taiwan, but sexual violence survivors' undermobilization of the law might also indicate their rejection of that myth. Therefore, the absence of \#MeToo in Taiwan can be considered an example of how the myth of rights facilitates and hinders mobilization for change under different conditions.

\section{WITH THE LAW, NOT DESPITE THE LAW}

\#MeToo demonstrates the limits of law, but it also exhibits the power of law, because the movement grew out of sexual harassment and assault laws and has led to judicial actions and legislative reforms. The absence of \#MeToo in Taiwan suggests the undermobilization of the law in both formal and informal settings, which further indicates the limits of the law in producing changes. In terms of the way forward, the question is not how to replicate the \#MeToo social media campaign to make Taiwan a member of the global \#MeToo community, but how and what to learn from the \#MeToo movement: how can we increase the victims' credibility and the perpetrators' accountability? The engagement of investigative journalism, while desperately needed, cannot do it alone. Should we aspire to the power of law and seek change through the law, or should we recognize the limits of law and pursue change despite the law?

Contending that it is more productive to situate the debate within \#MeToo in the context of "Sex War 2.0" (i.e., the return of the feminist sex war of the 1960s and 1970s), Cossman (2019) calls for a rethinking 
of sexual harm, women's agency, and the role of law, and she advocates for loosening the law's hold on the definition of sexual harm. Although her proposal is an invitation to rethink, rather than to reject, the role of law in regulating sexual harms to transcend feminist disagreements, it risks underestimating the power of law to produce change and overestimating the possibility of creating a carceral state. The law does have limits, and we should resist the legitimating effects of the myth of rights. However, we cannot make changes without law. \#MeToo litigations and legislation are taking place, and many have argued that the law should grow with \#MeToo (MacKinnon 2020; Rhode 2019; Rondeau 2019; Tippett 2018; Tuerkheimer 2019).

Proposals for change can be produced without\#MeToo. In her study of the hostile environment in Taiwan's hospitals, which reveals the role of the internal power structure in dealing with sexual harassment, Chang (2018) argues that organizations should pursue internal policy change along with more legal enforcement. Her analysis demonstrates how workplace antiharassment politics, procedures, and training programs operate as what Edelman (2020) calls "symbolic structures" that symbolize compliance but do not guarantee substantive results. Her proposal echoes Rhode's (2019) suggestion to sustain the \#MeToo momentum by addressing the limitations in law and legal enforcement, improving internal practices, and broadening the agenda. Taiwan's feminist movement introduced the first rape law reform that made lack of consent the core element of rape ("no means no") nearly two decades before \#MeToo. Advocacy for affirmative consent ("only yes means yes") is blooming and growing in Taiwan without \#MeToo, despite the controversy over whether it is the ideal feminist rape law. We can still make changes in the absence of \#MeToo, but butterflies like \#MeToo will make a critical intervention on our way forward.

Chao-ju Chen is Professor of Law and Director of the Women's and Gender Studies Program at National Taiwan University: cjtan@ntu.edu.tw

\section{REFERENCES}

Chang, C. F. 張晉芬. 2018. “Weihe wufa xiaochu diyi gongzuo huanjing? Fenxi yiyuan nei chuli xingsaorao shijian de quanli yunzuo 為何無法消除敵意工作環境? 分析醫 院內處理性騷擾事件的權力運作” [Why can't gender-based hostility be eradicated from the workplace? Analyzing power operations in dealing with sexual harassment in hospitals]. 社會科學論叢 [Review of Social Sciences] 12 (2): 1-42.

Clarke, Jessica A. 2019. “The Rules of \#MeToo." University of Chicago Legal Forum 2019: $37-84$. 
Cossman, Brenda. 2019. "\#MeToo, Sex Wars 2.0 and the Power of Law." Asian Yearbook of Human Rights and Humanitarian Law 3: 18-37.

Edelman, Lauren B. 2020. “The \#MeToo Movement, Symbolic Structures, and the Limits of the Law." In The Global \#MeToo Movement, eds. Ann M. Noel and David B. Oppenheimer. Washington, DC: Full Court Press, 445-57.

Fileborn, Bianca, and Rachel Loney-Howes. 2019. "Introduction: Mapping the Emergence of \#MeToo." In \#MeToo and the Politics of Social Change, eds. Bianca Fileborn and Rachel Loney-Howes. Cham, Switzerland: Palgrave Macmillan, 1-18.

MacKinnon, Catherine A. 2020. "Global \#MeToo." In The Global \#MeToo Movement, eds. Ann M. Noel and David B. Oppenheimer. Washington, DC: Full Court Press, $1-15$.

Noel, Ann M., and David B. Oppenheimer, eds. 2020. The Global \#MeToo Movement. Washington, DC: Full Court Press.

Rhode, Deborah L. 2019. “\#MeToo: Why Now? What Next?” Duke Law Journal 69 (2): 377-428.

Rondeau, D. Andew. 2019. “Opening Closed Doors: How the Current Law Surrounding Nondisclosure Agreements Serves the Interests of Victims of Sexual Harassment, and the Best Avenues for Its Reform." University of Chicago Legal Forum 2019: 583-614.

Scheingold, Stuart A. 1974. The Politics of Rights: Lawyers, Public Policy, and Political Change. New Haven, CT: Yale University Press.

- 2004. The Politics of Rights: Lawyers, Public Policy, and Political Change. 2nd ed. Ann Arbor: University of Michigan Press.

Sheu, C. J. 許春金. 1999. “Taiwan diqu xingqinhai fanzui zhuangkuan gyu xingtai zhi diao cha yanjiu 台灣地區性侵害犯罪狀況與型態之調查研究” [Survey research on the situations and types of sexual assault crimes in Taiwan]. Taipei: Sexual Harassment Prevention Committee, Ministry of Interior Affairs.

Taiwan Ministry of Labor 勞動部. 2020. “109 Nian guyong guanli ji gongzuo changsuo jiuye pingdeng gaikuang 109 年僱用管理及工作場所就業平等概況” [Overview of employment regulation and workplace equality in 2020]. https://www.mol.gov.tw/ announcement/2099/47801/ (accessed June 22, 2021)

Taiwan Police Institute 台灣警察學術研究學會. 2012. “Xingqinhai wenti zhi diaocha yanjiu 性侵害問題之調查研究” [Survey research on the issue of sexual assault]. https://ep.mohw.gov.tw/DOPS/cp-1 186-6500-105.html (accessed June 22, 2021).

Tippett, Elizabeth C. 2018. “The Legal Implications of the MeToo Movement.” Minnesota Law Review 103 (1): 229-302.

Tuerkheimer, Deborah. 2019. “Beyond \#MeToo.” New York University Law Review 94 (5): 1146-1208.

Zemans, Frances Kahn. 1983. "Legal Mobilization: The Neglected Role of the Law in the Political System.” American Political Science Review 77 (3): 690-703. 